\title{
(-)-Oleocanthal Combined with Lapatinib Treatment Synergized against HER-2 Positive Breast Cancer In Vitro and In Vivo
}

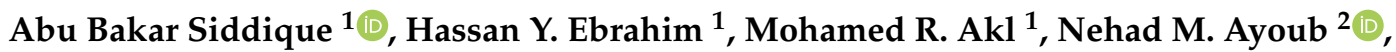 \\ Amira A. Goda ${ }^{1}$, Mohamed M. Mohyeldin ${ }^{1}$, Suresh K. Nagumalli ${ }^{1}$, Wael M. Hananeh ${ }^{3} \mathbb{D}$, \\ Yong-Yu Liu ${ }^{1}$, Sharon A. Meyer ${ }^{1}$ and Khalid A. El Sayed ${ }^{1, *(D)}$ \\ 1 School of Basic Pharmaceutical and Toxicological Sciences, College of Pharmacy, University of Louisiana \\ at Monroe, 1800 Bienville Drive, Monroe, LA 71201, USA; siddiqab@warhawks.ulm.edu (A.B.S.); \\ hassanchem.phd@outlook.com (H.Y.E.); mohamedreda_pharmacy@yahoo.com (M.R.A.); \\ amirakareem16@gmail.com (A.A.G.); mohyelmm@warhawks.ulm.edu (M.M.M.); \\ nagumask@warhawks.ulm.edu (S.K.N.); yliu@ulm.edu (Y.-Y.L.); meyer@ulm.edu (S.A.M.) \\ 2 Department of Clinical Pharmacy, Faculty of Pharmacy, Jordan University of Science and Technology, \\ Irbid 22110, Jordan; nmayoub@just.edu.jo \\ 3 Department of Pathology and Public Health, Faculty of Veterinary Medicine, Jordan University of Science \\ and Technology (JUST), Irbid 22110, Jordan; whananeh@just.edu.jo \\ * Correspondence: elsayed@ulm.edu; Tel.: +1-318-342-1725
}

Received: 28 December 2018; Accepted: 11 February 2019; Published: 15 February 2019

check for updates

\begin{abstract}
Dysregulation of epidermal growth factor receptor (EGFR)/human epidermal growth factor-2 (HER2) family is a hallmark of aggressive breast cancer. Small-molecule tyrosine kinase inhibitors are among the most effective cancer targeted treatments. (-)-Oleocanthal (OC) is a naturally occurring phenolic secoiridoid lead from extra-virgin olive oil with documented anti-cancer activities via targeting mesenchymal epithelial transition factor (c-Met). Dysregulation of c-Met promotes aggressiveness to breast cancer-targeted therapies. Lapatinib (LP) is an FDA-approved dual EGFR/HER2 inhibitor for HER2-amplified breast cancer. HER2-Positive tumor cells can escape targeted therapies like LP effects by overexpressing c-Met. Combined OC-LP treatment is hypothesized to be mechanistically synergistic against HER2-overexpressing breast cancer. Combined sub-effective treatments of OC-LP resulted in synergistic anti-proliferative effects against the HER2-positive BT-474 and SK-BR-3 breast cancer cell lines, compared to OC or LP monotherapy. Antibody array and Western blot analysis showed that combined OC-LP treatment significantly inhibited EGFR, HER2, and c-Met receptor activation, as well as multiple downstream signaling proteins, compared to individual OC or LP treatment. OC-LP Combination significantly inhibited invasion and migration of breast cancer cells through reduced activation of focal adhesion kinase (FAK) and paxillin. Combined treatment of OC-10 mg/ $\mathrm{kg}$ with LP- $12.5 \mathrm{mg} / \mathrm{kg}$ suppressed more than $90 \%$ of BT-474 tumor cells growth in a nude mouse xenograft model, compared to individual OC or LP treatment. Activated c-Met, EGFR, HER2, and protein kinase B (AKT) were significantly suppressed in combination-treated mice tumors, compared to OC or LP monotherapy. This study reveals the OC future potential as combination therapy to sensitize HER2-overexpressing breast cancers and significantly reduce required doses of targeted HER family therapeutics.
\end{abstract}

Keywords: breast cancer; combination; HER2/neu; lapatinib; c-Met; (-)-Oleocanthal 


\section{Introduction}

The epidermal growth factor (ErbB, HER) family consists of four transmembrane receptor tyrosine kinases (RTKs); HER1 to HER4 [1]. Their dysregulations are strongly implicated in the pathogenesis of various human malignancies, associated with poor prognostic outcomes, aggressive phenotype profile, and poor disease outcomes, including reduced overall survival [2-5]. About $20-30 \%$ of breast cancer (BC) cases are characterized by overexpression of HER2 [6,7]. The introduction of effective HER2-targeted therapies in clinical practice has dramatically improved outcomes among HER2-positive BC patients $[3,6,8]$. One of the clinically available HER2-targeted therapies is lapatinib (LP), an orally active small-molecule dual tyrosine kinase inhibitor (TKI) of epidermal growth factor receptor (EGFR) and HER2 kinases [8,9]. Through inhibiting receptor activation, LP suppressed downstream signaling of HER2 through major downstream proteins, such as extracellular signal-regulated kinases (ERK) $1 / 2$ and AKT $[10,11]$. Despite success as HER2-targeted therapy, limitations to LP treatment monotherapy involved the emergence of both primary and acquired resistance among HER2-positive BC patients and multiple off-target side effects [12-14]. Non-HER2-targeted therapy has also been shown to be a promising strategy of overcoming resistance and restoring the activity of HER2-targeted treatments [15].

c-Met is an RTK associated with BC development and progression [16,17]. Activation of c-Met in cancer cells by its natural ligand, the hepatocyte growth factor (HGF), accelerates proliferation, scattering, migration, invasion, and metastasis [16]. c-Met crosstalk with HER RTK members and can be a dimerization partner with HER2 [18]. Amplification of c-Met also promotes resistance to multiple anti-HER targeted therapies [18-21]. Thus, it is hypothesized that multi-targeted combination therapy using c-Met inhibitor could be appealing to enhance treatment effects of anti-HER2 targeted therapies and chemosensitize HER2-positive BC.

(-)-Oleocanthal (OC) is a natural phenolic secoiridoid from extra-virgin olive oil (EVOO) known for its anti-oxidant, anti-bacterial, and anti-inflammatory activities [22-25]. The anticancer activity of $\mathrm{OC}$ has been demonstrated in cell culture and animal models against different cancer types, including breast, prostate, colorectal, skin, and hepatocellular carcinoma [24-26]. In BC, OC was shown to effectively inhibit proliferation, migration, and invasion of BC cells both in vitro and in vivo [22,24-26]. Molecular modeling, cell culture, and animal studies clearly revealed c-Met as a molecular target to OC, through inhibiting its tyrosine kinase domain $[27,28]$. The anticancer activity of OC was associated with the suppression of multiple downstream effectors, such as the phosphoinositide-3 (PI3K)-AKTmechanistic target of rapamycin (mTOR), protein superfamily of small guanosine triphosphatases (Ras)- Mitogen-activated protein kinase (MAPK), Janus kinase (JAK)- Signal transducer and activator of transcription 3 (STAT), and heat shock protein-90 (HSP90) signaling pathways [25,27-31].

Considering the crosstalk between c-Met and the HER family receptors [18-20], along with its involvement in mediating resistance to anti-HER targeted therapies [18-21], for the first time this study primarily aimed to investigate the in vitro and in vivo effectiveness of the combined treatments of the c-Met inhibitor EVOO-derived phenolic lead OC with the targeted therapeutic anti-EGFR/HER2 drug LP against HER2-positive BC.

\section{Materials and Methods}

\subsection{Chemicals, Reagents, and Antibodies}

All reagents purchased from Sigma-Aldrich (St. Louis, MO, USA), unless otherwise stated. All primary, secondary antibodies are purchased from Cell Signaling Technology (Beverly, MA, USA), unless otherwise stated. Hepatocyte growth factor (HGF) and epidermal growth factor (EGF) purchased from PeproTech Inc. (Rocky Hill, NJ, USA). Lapatinib (LP) purchased from AstaTech, Bristol, PA, USA. 


\subsection{Cell Lines and Culture Conditions}

Human BC cell lines BT-474 and SK-BR-3, as well as the non-tumorigenic MCF-12A human mammary epithelial cells obtained from the American Type Culture Collection (ATCC, Manassas, VA, USA). Both BT-474 and SK-BR-3 are HER2-enriched BC cells and responsive to the anti-HER2 therapy trastuzumab [32]. BC cells were cultured in Roswell Park Memorial Institute (RPMI-1640) /Dulbecco's Modified Eagle's medium (DMEM) media supplemented with $10 \%$ fetal bovine serum (FBS), penicillin G (100 U/mL) and streptomycin $(100 \mathrm{ng} / \mathrm{mL})$. MCF-12A cells were maintained in DMEM/F12 media supplemented with $5 \%$ horse serum, $0.5 \mu \mathrm{g} / \mathrm{mL}$ hydrocortisone, $20 \mathrm{ng} / \mathrm{mL}$ EGF, $100 \mathrm{U} / \mathrm{mL}$ penicillin $\mathrm{G}, 0.1 \mathrm{mg} / \mathrm{mL}$ streptomycin, and $10 \mu \mathrm{g} / \mathrm{mL}$ insulin. All cells were maintained in a humidified incubator at $37{ }^{\circ} \mathrm{C}$ with $5 \% \mathrm{CO}_{2}$. For sub-culturing, cells were washed with $\mathrm{Ca}^{2+}$ and $\mathrm{Mg}^{2+}$-free phosphate-buffered saline (PBS) and incubated in $0.05 \%$ trypsin containing $0.02 \%$ Ethylenediaminetetraacetic acid (EDTA) in PBS for $5-15$ min at $37^{\circ} \mathrm{C}$.

\subsection{Experimental Treatments}

OC was extracted from EVOO (The Governor, batch 5-214000-242017) [27-29] using liquid-liquid extraction process and further purification has been done using Sephadex LH-20 column purity of OC was determined using HPLC analysis on a Shimadzu high-performance liquid chromatography (HPLC) system equipped with ultra violet (UV)/Visible variable wavelength detector and a purity of $>99 \%$ was confirmed [27-29]. Quantitative ${ }^{1} \mathrm{H}$ NMR in deutrated chloroform- $\mathrm{d}_{3}\left(\mathrm{CDCl}_{3}\right)$ was acquired on a JEOL Eclipse ECS-400 nuclear magnetic resonance (NMR) spectrometer. OC and LP dissolved in dimethyl sulfoxide (DMSO) to provide a $25 \mathrm{mM}$ stock solution. These stock solutions used to prepare various treatment concentrations. The final concentration of DMSO maintained the same in all treatment groups within a given experiment and never exceeded $0.1 \%$.

\subsection{Cell Viability Assay}

Cells were seeded into a 96-well plate at a density of $1 \times 10^{4}$ cells/well (6 replicates/group) in $10 \%$ FBS RPMI-1640 media and allowed to attach overnight. Next day, cells were divided into different treatment groups and exposed to respective control or experimental treatments with various concentrations of either OC or LP alone or in combination for $48 \mathrm{~h}$ in media containing $40 \mathrm{ng} / \mathrm{mL}$ of HGF and EGF as mitogens. At the end of treatment duration, the viable cell number was determined using 3-(4,5-dimethylthiazol-2-yl)-2,5-diphenyl-tetrazolium bromide (MTT) assay [33]. MTT was added to each well at a final concentration of $1.0 \mathrm{mg} / \mathrm{mL}$. After $4 \mathrm{~h}$ incubation at $37^{\circ} \mathrm{C}$, media was removed, and formazan crystals were dissolved in DMSO (100 $\mu \mathrm{L} /$ well). Optical density was measured at $570 \mathrm{~nm}$ on a microplate reader (BioTek, Winooski, VT, USA). The number of cells/well was calculated against a standard curve prepared by plating various numbers of cells at the start of each experiment.

\subsection{Western Blot Analysis}

BC cells were initially plated at $1 \times 10^{6}$ cells $/ 100 \mathrm{~mm}$ culture plates in Roswell Park Memorial Institute (RPMI)-1640 media supplemented with 10\% fetal bovine serum (FBS) and allowed to adhere overnight. Cells were then washed with phosphate buffered saline (PBS) and treated with the respective control or treatment media containing various concentrations of OC, LP, or their combination for $48 \mathrm{~h}$. Cells were then harvested and washed twice with cold PBS, resuspended and lysed in Radioimmunoprecipitation assay (RIPA) buffer (Qiagen Sciences Inc., Valencia, CA, USA) at $4{ }^{\circ} \mathrm{C}$ for $30 \mathrm{~min}$. Lysates were centrifuged for $10 \mathrm{~min}$ at $14,000 \times \mathrm{g}$ and supernatants were stored at $-80{ }^{\circ} \mathrm{C}$ as whole cell extracts. Protein concentration was determined by the Pierce BCA Protein Assay (Thermo Fisher Scientific Inc., Rockford, IL, USA). Proteins were separated on 10\% sodium dodecyl sulfate polyacrylamide gel electrophoresis (SDS-PAGE) gels and transferred to polyvinylidene difluoride membranes. Membranes blocked with $2 \%$ bovine serum albumin (BSA) and incubated with the indicated primary antibodies. Corresponding horseradish peroxidase-conjugated secondary 
antibodies were used against each primary antibody. Proteins were detected using ChemiDoc XRS chemiluminescent gel imaging system and analyzed using Image Lab software (Bio-RAD, Hercules, CA, USA) $[27,28]$. Visualization of $\beta$-tubulin was used to ensure equal sample loading in each lane. Experiments were repeated three times and representative image presented in figures.

\subsection{Cell Cycle Assay}

Cells in the various treatment groups were trypsinized and then resuspended in ice cold PBS, fixed with cold $\left(-20^{\circ} \mathrm{C}\right) 70 \%$ ethanol, and stored at $4{ }^{\circ} \mathrm{C}$ for $2 \mathrm{~h}$. Afterwards, cells were rehydrated with ice cold PBS and then incubated with DNA staining buffer (sodium citrate $1 \mathrm{mg} / \mathrm{mL}$, Triton-X-100 $3 \mu \mathrm{L} / \mathrm{mL}$, propidium iodide (PI) $100 \mu \mathrm{g} / \mathrm{mL}$, ribonuclease A $20 \mu \mathrm{g} / \mathrm{mL}$ ) for $30 \mathrm{~min}$ at $4{ }^{\circ} \mathrm{C}$ in the dark. DNA content was then analyzed using a fluorescence-activated cell sorter (FACS) Calibur flow cytometer (BD Biosciences, San Jose, CA, USA). For each sample, 10,000 events were recorded, and histograms were generated using CellQuest software (BD Biosciences, San Jose, CA, USA) [27]. All experiments were repeated at least three times.

\subsection{Cell Apoptosis Assay}

Cell apoptosis assay was conducted using Annexin V- Fluorescein isothiocyante (FITC) Early apoptosis detection kit (Cell Signaling Technology, Beverly, MA, USA). Cells in each treatment group were trypsinized and then washed twice with ice cold PBS, stained with Annexin V-FITC and PI in the binding buffer, and detected by flow cytometry (FCM) after $10 \mathrm{~min}$ incubation at room temperature in the dark. Dot plots were generated using CellQuest software (BD Biosciences, San Jose, CA, USA) [27].

\subsection{Antibody Array}

Explorer Antibody Microarray conducted using Full Moon Biosystems; Sunnyvale, CA, USA. Protocol is available at https://www.fullmoonbio.com/products/antibody-array/.

\subsection{Migration and Invasion Assays}

Migration and invasion of BC cells were assessed using CytoSelect 24-well Cell Migration and Invasion Assay kit (CBA-100-C, Cell Biolabs) following manufacturer instructions [27,28]. In brief, $1.5 \times 10^{5}$ cells placed on an $8-\mu \mathrm{M}$ pore size insert. After incubation for $24 \mathrm{~h}$ or $48 \mathrm{~h}$, the non-migratory/non-invasive cells the upper chamber were carefully removed with cotton-tipped swabs, and the migratory/invasive cells processed per vendor's protocol and read by a plate reader (Versamax tunable microplate reader, Molecular Devices) at $\lambda 560 \mathrm{~nm}$. Before removing the cells from the upper chamber, the non-migratory cells visualized by a Nikon ECLIPSE TE200-U microscope (Nikon Instruments Inc., Melville, NY, USA). Digital images were captured using Nikon NIS Elements software (Nikon Instruments Inc., Melville, NY, USA).

\subsection{BT-474 Nude Mice Xenograft Tumor Model}

Foxn ${ }^{1 \mathrm{nu}} /$ Foxn $^{1+}$ nude mice were obtained from Envigo (Indianapolis, IN, USA) and maintained with sterilized food and water. All procedures were conducted in accordance with the recommendations in the Guide for the Care and Use of Laboratory Animals [34] and approved by the University of Louisiana-Monroe Institutional Animal Care and Use Committee (IACUC, Protocol Number: 15OCT-KES-01). Five female nude mice at 4-5 weeks old, 20-23 g average weight, used for each group. Mice were anaesthetized using ketamine and xylazine mixture as previously described [27,28]. A 0.72-mg 60-day release 17 $\beta$-estradiol pellet (Innovative Research) was then implanted into the interscapular region of each mouse. Every mouse was then subcutaneously injected with BT-474 cells $\left(5 \times 10^{6}\right.$ cells in 30:30 $\mu \mathrm{L}$ Matrigel/RPMI-1640) under the second mammary gland fat pad $[27,28]$. When tumors were palpable, $30-40 \mathrm{~mm}^{3}$ volume average, and of the same volume at 14 days, the mice were randomized into four different groups and treated with the following 
treatments: (i) Vehicle control (DMSO/saline), intraperitoneal (ip), using the maximal volume used for treatments; (ii) OC $10 \mathrm{mg} / \mathrm{kg}$, ip, 3X/week; (iii) LP $12.5 \mathrm{mg} / \mathrm{kg}$, oral, 5X/week; (iv) OC $10 \mathrm{mg} / \mathrm{kg}$, ip, 3X/week plus LP $12.5 \mathrm{mg} / \mathrm{kg}$, oral, 5X/week. Mice were monitored by measuring tumor volume every third day, body weight and clinical observation. Tumor volume (V) was calculated using the formula $\mathrm{V}=\left(\mathrm{L} \times \mathrm{W}^{2}\right) / 2$. Percentage of tumor growth inhibition (\% TGI) was measured on the last day of study for drug-treated compared with vehicle-treated mice. \% TGI is calculated as $100 \times\{1-$ [(treated final day - treated day 1)/(control final day - control day 1)]\} [27,28,30].

\subsection{Hematoxylin and Eosin $Y(H \mathcal{E} E)$ Staining}

Tumor sample portions were cut into small slices (3-5 mm thick), and fixed in $10 \%$ neutral buffered formalin for $48 \mathrm{~h}$. The tissues were transferred to $70 \%$ ethanol, processed, and embedded in paraffin. Paraffin-embedded tumors were sliced into $5 \mu \mathrm{M}$ sections using a Leica RM2035 microtome and mounted on positively charged slides. Paraffin sections were dewaxed in xylene, rinsed in alcohol, rehydrated in water and finally tumor slides were stained with H\&E. Following the last submersion into xylene, the slides were permanently mounted using permount and a coverslip.

\subsection{Statistics}

Values are expressed as mean \pm standard error mean (S.E.M.) and analyzed using statistical package for GraphPad Prism software version 8 using One-way ANOVA followed by Tukey's test; $p<0.05$ were considered statistically significant. IC $_{50}$ was determined using GraphPad Prism software version 8 . Combination data were analyzed, and results showed as combination index (CI) values according to the median-effect principle, where $\mathrm{CI}<1,=1$, and $>1$ indicate synergism, additive effect, and antagonism, respectively. $C I$ values calculated as follows: $C I=\left[X_{c} / X+T_{c} / T\right]$, where $X$ and $\mathrm{T}$ stand for the concentrations of individual combination ingredients, $\mathrm{OC}$ and LP, that induce $50 \%$ cell growth inhibition $\left(\mathrm{IC}_{50}\right) ; \mathrm{X}_{\mathrm{C}}$ and $\mathrm{T}_{\mathrm{C}}$ are the concentrations of combination ingredients that induce $50 \%$ cell growth inhibition when used combined as determined by non-linear regression curve fit analysis [28,35]. Dose reduction index (DRI) values for OC and LP calculated as follows: DRI (-)-Oleocanthal $=\mathrm{OC} \mathrm{IC} \mathrm{I}_{50} / \mathrm{OC}$ combination $\mathrm{IC}_{50}$ and DRI lapatinib $=\mathrm{LP} \mathrm{IC}_{50} / \mathrm{LP}$ combination $\mathrm{IC}_{50}$.

\section{Results}

\subsection{Effect of OC, LP, and Their Combined Treatments on Growth of HER2-Positive BC and} Non-Tumorigenic Cells

The anti-proliferative activity of OC-LP was evaluated in BT-474 and SK-BR-3 cells, representing HER2-positive BC (Figure 1A-D). Monotherapy of OC or LP treatments showed a dose-dependent inhibition of growth of BT-474 and SK-BR-3 cells, with $\mathrm{IC}_{50}$ values of $25.1 \mu \mathrm{M}, 27.3 \mu \mathrm{M}, 123.0 \mathrm{nM}$ and $117.3 \mathrm{nM}$, respectively. OC showed minimal effects on the viability of the non-tumorigenic mammary epithelial MCF12A cells with an $\mathrm{IC}_{50}$ of $82.6 \mu \mathrm{M}$ after $48 \mathrm{~h}$ treatments (Figure 1E). OC was selective to malignant cells.

To assess the effect of combined OC and LP treatments, BT-474 and SK-BR-3 BC cells treated with sub- $\mu \mathrm{M}$ doses of OC at $12 \mu \mathrm{M}$ or $15 \mu \mathrm{M}$, respectively (Figure $2 \mathrm{~A}, \mathrm{~B}$ ). Isobologram analysis of the effect of OC and LP combination treatments in both cell lines indicated synergistic inhibition of cell growth (Figure 2C,D). Calculated combination index (CI) value for the combination treatments of OC-LP indicated synergism, with values less than 1 in both BT-474 and SK-BR-3 cells (Supplementary Table S1). In BT-474 cells, the CI value was 0.74 for a combined $30 \mathrm{nM}$ LP and $12 \mu \mathrm{M}$ OC treatment. In SK-BR-3 cells the CI value was 0.87 for $60 \mathrm{nM}$ LP and $15 \mu \mathrm{M}$ OC combined treatment. In addition, the dose reduction index (DRI) values for combined OC-LP treatments showed multiple-fold reductions of both compounds (Supplementary Table S1). After determining the OC and LP interaction levels and the concentrations resulting in synergism, subsequent experiments were conducted using OC $12 \mu \mathrm{M}$ with $30 \mathrm{nM}$ LP in BT-474 cells and OC $15 \mu \mathrm{M}$ with $60 \mathrm{nM}$ LP in SK-BR-3 cells. 


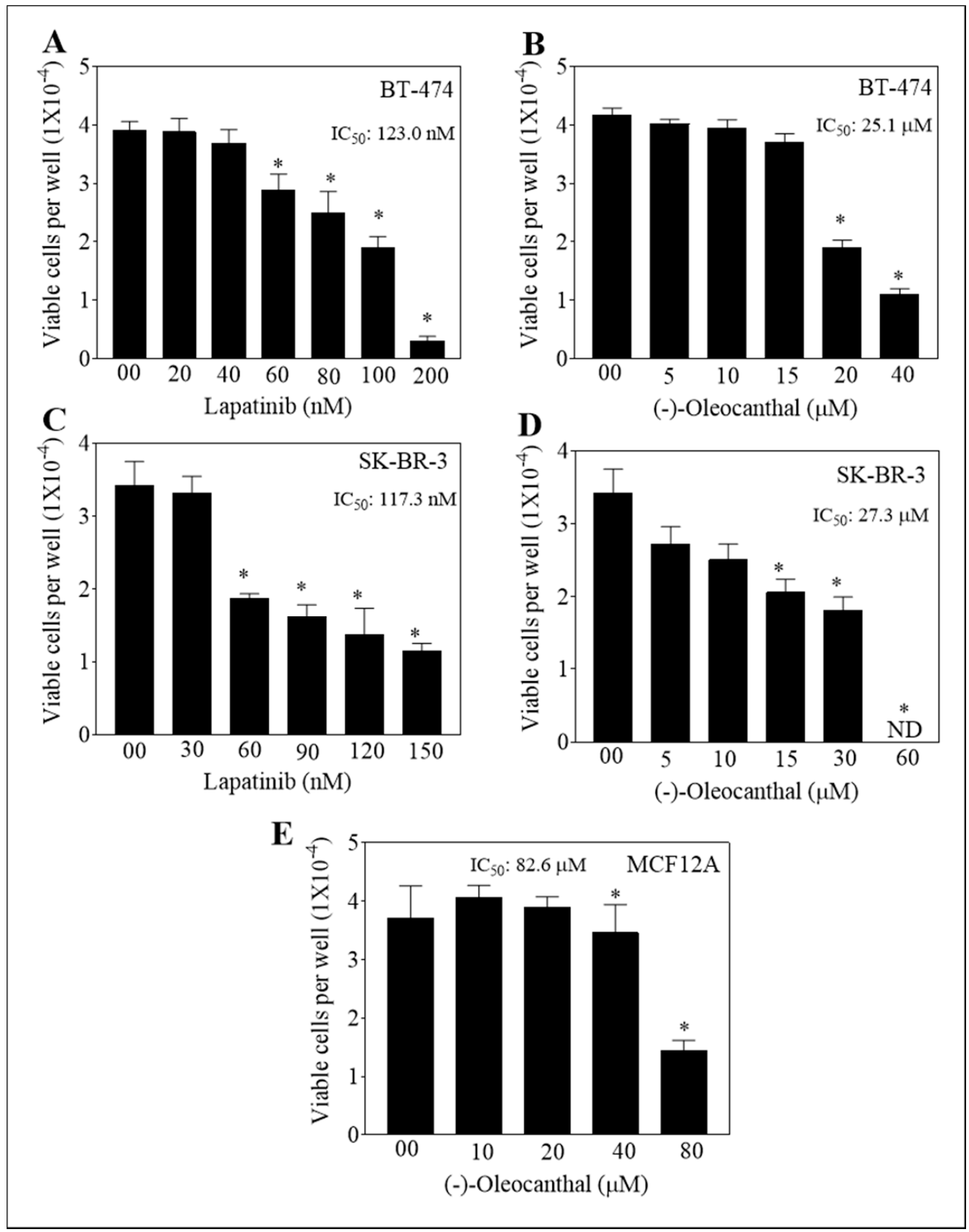

Figure 1. Effect of (-)-Oleocanthal (OC) and Lapatinib (LP) treatment on the growth of HER2-overexpressing BC cells. (A,B) Effect of LP or OC treatment on the growth of BT-474 cells after $48 \mathrm{~h}$ culture period. (C,D) Effect of LP or OC treatment the on growth of SK-BR-3 cells after $48 \mathrm{~h}$ culture period. (E) Effect of OC treatment on the growth of MCF-12A cells after $48 \mathrm{~h}$ culture period. In these assays, cells were plated at a density of $1 \times 10^{4}$ cells/well in 96-well plates and maintained in media supplemented with $10 \%$ FBS and allowed to adhere overnight. Cells then treated with vehicle-control or increasing concentrations of OC or LP in serum-free media containing hepatocyte growth factor (HGF) and Epidermar growth factor (EGF) $40 \mathrm{ng} / \mathrm{mL}$ as mitogens for $48 \mathrm{~h}$. At the end of treatment, viable cell number determined by the MTT colorimetric assay. Vertical bars indicate mean cell count $\pm \operatorname{SEM}(n=6)$ in each treatment group. ${ }^{*} p<0.05$ as compared with vehicle-treated controls. ND, not detectable. 


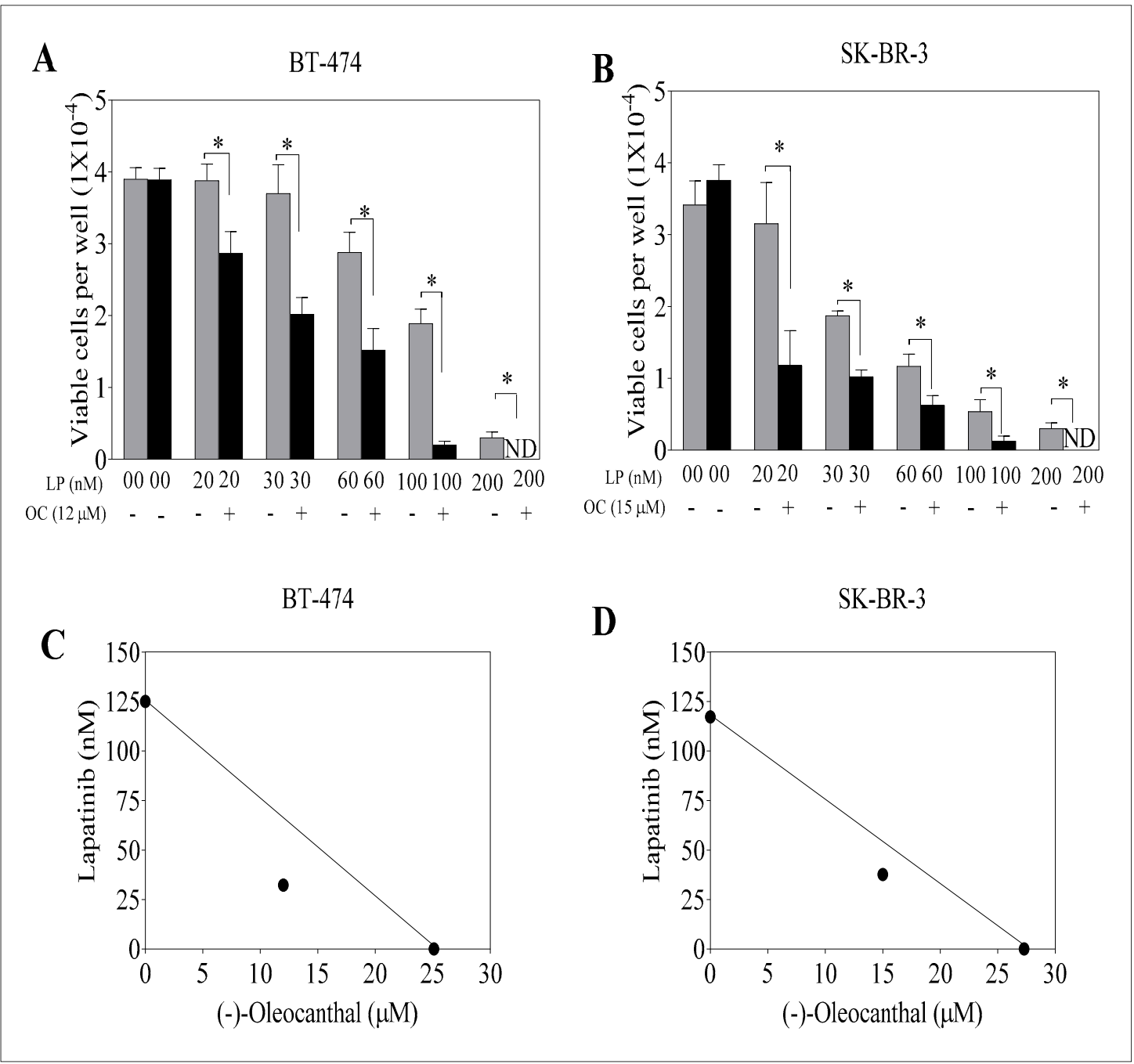

Figure 2. Effect of combined OC and LP treatments on growth of HER2-overexpressing BC cells. (A) Effect of sub-effective OC and LP combined treatment on BT-474 cells after $48 \mathrm{~h}$ culture period. (B) Effect of sub-effective OC and LP combined treatment on SK-BR-3 cells after $48 \mathrm{~h}$ culture period. Cells were plated at a density of $1 \times 10^{4}$ cells/well in 96-well plates and maintained in media supplemented with $10 \%$ FBS and allowed to adhere overnight. Next day, cells were treated with vehicle-control or sub- $\mu \mathrm{M}$ dose of OC or $\mathrm{nM}$ dose of LP either alone or combined in serum-free media containing HGF and EGF $40 \mathrm{ng} / \mathrm{mL}$ as mitogens for $48 \mathrm{~h}$. At the end of treatment, viable cell number determined by the MTT colorimetric assay. Vertical bars indicate the mean cell count $\pm \operatorname{SEM}(n=6)$ in each treatment group. ${ }^{*} p<0.05$ as compared with individual LP treatment. (C,D) Isobolograms of combined OC and LP anti-proliferative effect in BT-474 and SK-BR-3 cells, respectively. IC 50 concentrations for OC and LP plotted on the $X$ - and $Y$-axis, respectively. The solid line connecting these points represents the concentration of each compound required to induce the same relative growth inhibition when used in combination if the interaction between the compounds is additive. The data point on each isobologram represents the actual concentrations of OC and LP, which induced 50\% inhibition of cell growth when used in combination. ND; not detectable. 


\subsection{Effect of Combined OC and LP Treatment on Target RTKs and Downstream Effectors in HER2-Positive BC Cells}

To investigate the effects of OC-LP combination on the total and active levels of MET, HER2, and EGFR RTKs, Western blot analysis was performed. Both BC cell lines treated with individual or combined OC and LP for $48 \mathrm{~h}$. Combined OC-LP treatment significantly suppressed the activation of c-Met, HER2, and EGFR in both cell lines as indicated by reduced receptor phosphorylation levels compared to individual OC or LP treatment (Figure 3). However, in BT-474 cells combination treatment slightly reduced the activated levels of c-Met, HER2, and EGFR, which may be because of OC individual effect since it also reduced the total levels of c-Met, HER2, and EGFR (Figure 3). In addition, BT-474 cells combined OC-LP treatment did not affect the PI3K downstream signaling but significantly suppressed the activation of AKT (Figure 3), compared to individual OC or LP treatment. In SK-BR-3 cells combination treatment reduced total c-Met and EGFR but eventually there is no effect of LP on p-Met reduction. Although, OC individual and combination treatment reduced PI3K downstream signaling protein, but combination treatment significantly suppressed the activation of AKT as compared to individual OC or LP treatment (Figure 3).

\subsection{Effect of Combined OC and LP Treatment on Cell Cycle Progression in HER2-Positive BC Cells}

To further investigate the molecular mechanisms associated with growth suppression observed with combined OC-LP treatment, cell cycle analysis was assessed by flow cytometry applying propidium iodide (PI) staining (Supplementary Figure S1A). Cell cycle analysis demonstrated an increase in the proportion of BT-474 cancer cells in G1 phase in combined OC-LP treatment (58\%), compared to G1 cells in the vehicle control treatment (53\%, Supplementary Figure S1B). However, the impact of combined OC-LP treatment on the G1 cell population was less remarkable in SK-BR-3 cells (Supplementary Figure S1B). Supplementary Figure S1C shows the effect of OC-LP combination treatments on cell cycle key regulatory molecules. Western blot analysis showed that combined OC-LP treatment resulted in downregulation of cyclins D1 and D3, as well as reduced total levels of cyclin-dependent kinase-6 (CDK-6) in both BT-474 and SK-BR-3 cells (Supplementary Figure S1C). In addition, the combination was associated with increased total levels of cell cycle arrest proteins $\mathrm{p} 21$, also known as p21 WAF1/Cip1, and p27 in treated cancer cells, compared to their respective vehicle-treated control groups (Supplementary Figure S1C).

\subsection{Pro-Apoptotic Effects of Combined OC-LP Treatment in HER2-Positive BC Cells}

The cytotoxic activity of combined OC-LP treatment was assessed using the apoptotic marker Annexin $\mathrm{V}$ and the oncotic marker PI in treated breast cancer cells applying flow cytometry (Figure 4A). In BT-474 cells, treatment with OC $(12 \mu \mathrm{M})(1.25 \%)$, LP $(30 \mathrm{nM})(0.68 \%)$, or the combination treatment $(1.17 \%)$ did not increase Annexin $\mathrm{V}$ labeling among treatment groups as compared to control cells $(1.38 \%$, Figure 4B), which indicated cytostatic rather than cytotoxic effect. Meanwhile, combined treatment of OC $(15 \mu \mathrm{M})$ with LP $(60 \mathrm{nM})$ also increased the proportion of SK-BR-3 cells with positive Annexin V staining (26.3\%), compared to the vehicle-treated control cells (2.44\%, Figure 4B). Surprisingly, OC individual treatment induced significant early apoptosis (17\%), compared to LP treatment (9.08\%) in SK-BR-3 cells. Furthermore, Western blot analysis further revealed the apoptotic effect in treated SK-BR-3 cells as indicated by increased cleaved caspase 3 and cleaved Poly (ADP-ribose) polymerase (PARP) expressions with either OC individual or combined OC-LP treatments (Figure 4C). Apoptosis markers were not detected in BT-474 cells treated with either individual OC or LP or combined, compared to the vehicle control-treated cells as indicated by lack of cleaved caspase 3 and cleaved PARP (Figure 4C). 


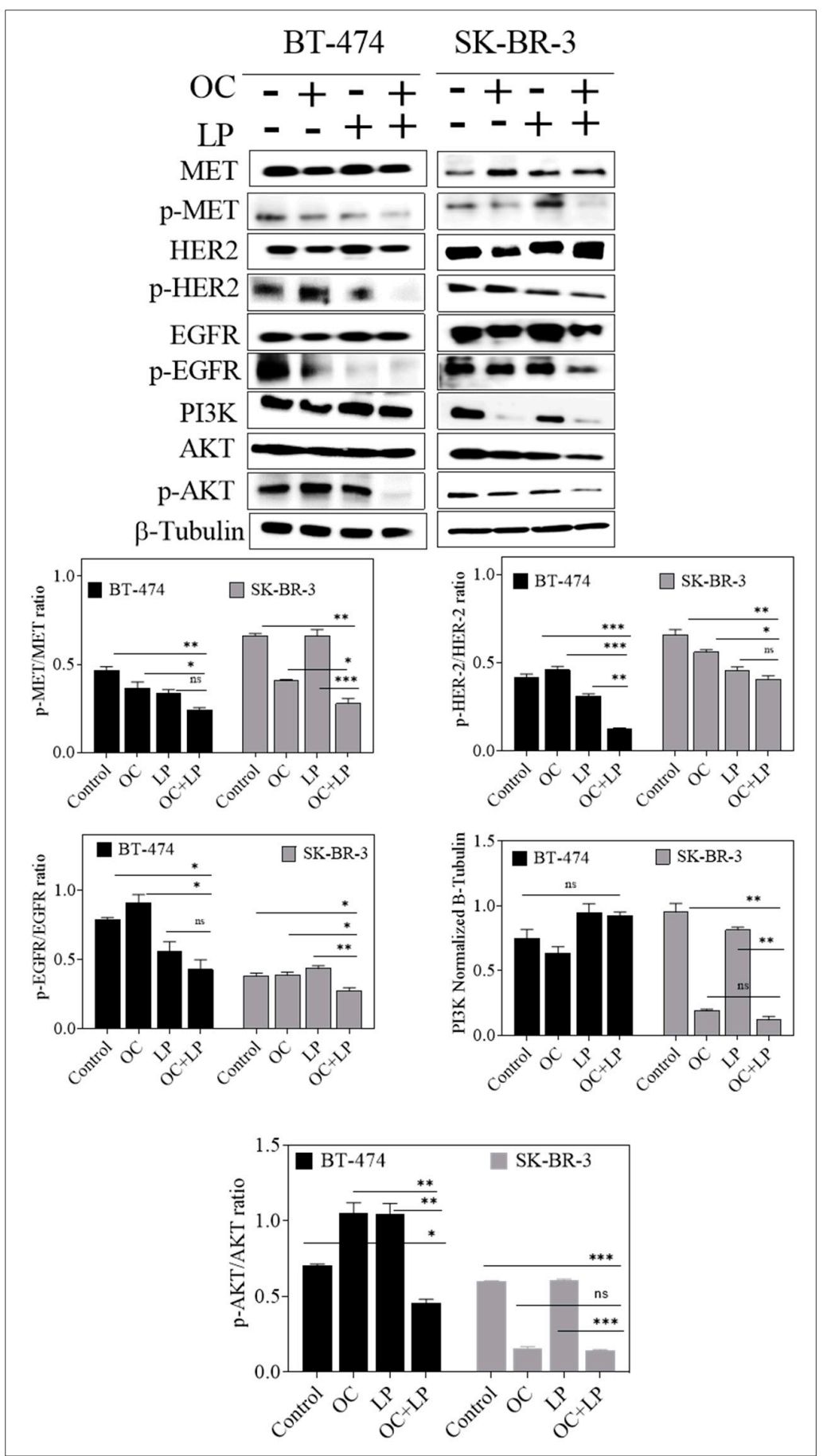

Figure 3. Effect of combined OC and LP treatment on target RTKs and downstream effectors and proliferation markers in HER2-positive BC cells. Western blot analysis for the effect of combined OC and LP treatment on RTKs, and PI3K/AKT signaling pathways. Cells were plated at $1 \times 10^{6}$ cells /100 mm culture plates in RPMI-1640 media supplemented with 10\% FBS and allowed to adhere overnight. Next day, cells incubated with respective OC, LP, or combined treatment in serum-free media containing HGF and EGF $40 \mathrm{ng} / \mathrm{mL}$ as mitogens for $48 \mathrm{~h}$. At the end of the treatment period, the whole cell lysates were prepared then subjected to polyacrylamide gel electrophoresis and Western blot analysis. $\beta$-Tubulin was visualized to ensure equal sample loading in each lane. Image Lab densitometric analysis performed on all blots and the integrated optical density of each band was normalized with the corresponding $\beta$-tubulin, as shown under their respective Western blot images. ${ }^{*} p<0.05,{ }^{* * *} p<0.001$ as compared with either individual OC or LP treatment or vehicle treatment. 


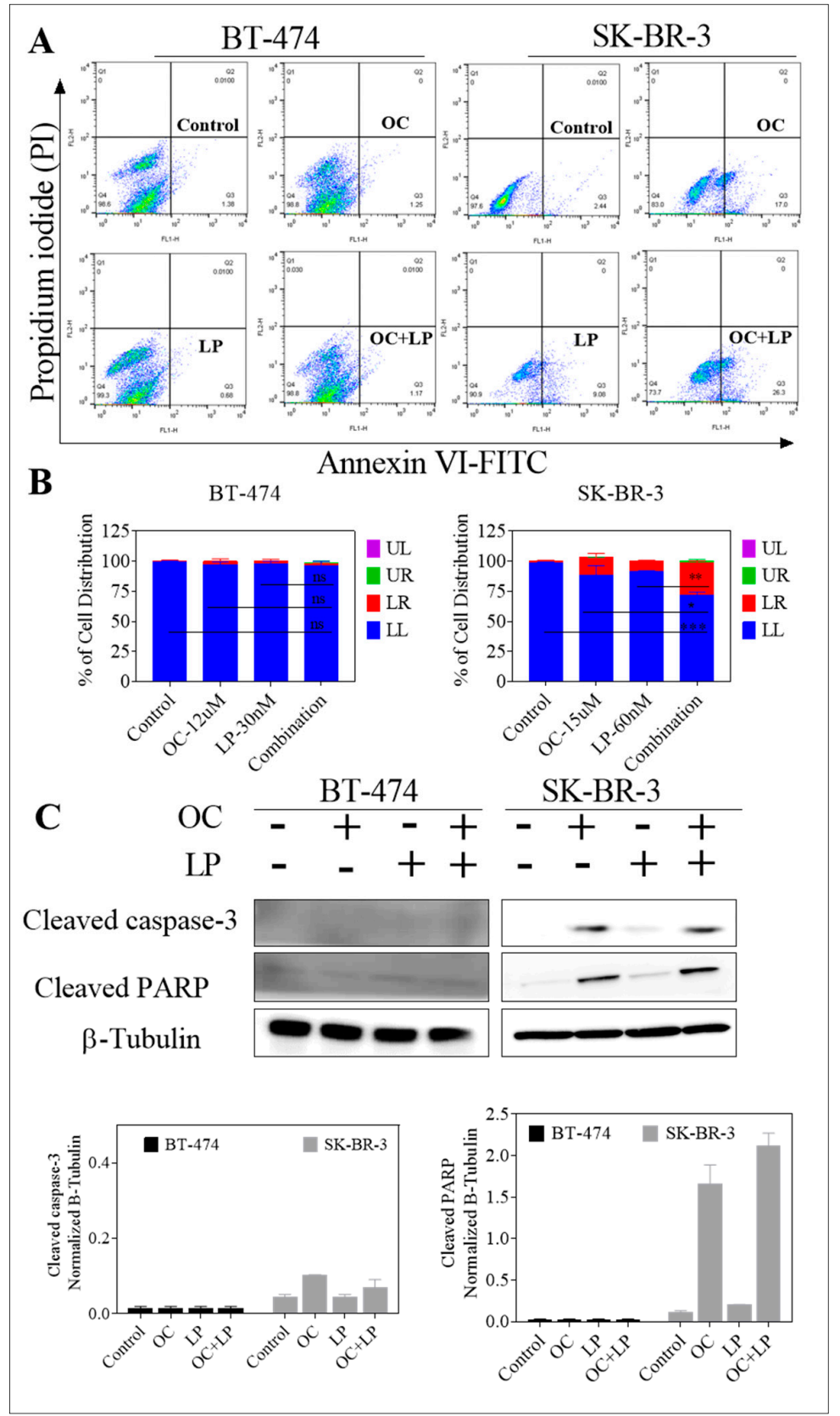

Figure 4. Pro-apoptotic effects of combined OC-LP treatment in HER2-positive BC cells. (A) Flow cytometry analysis for OC combined with LP treatment in BT-474 and SK-BR-3 BC cells. Cells were plated at a density of $5 \times 10^{6}$ cells $/ 100 \mathrm{~mm}$ culture plates, allowed to attach overnight. Afterwards, cells were incubated in the respective control, OC, LP, or LP-OC combination in RPMI-1640 medium containing $40 \mathrm{ng} / \mathrm{mL}$ HGF and EGF for $24 \mathrm{~h}$. At the end of the experiment, cells in each treatment group were trypsinized, washed then resuspended in ice-cold 1X Annexin V binding buffer. Afterwards, cells treated as described earlier. In the dot plot of double variable flow cytometry, LL quadrant $\left(\mathrm{FITC}^{-} / \mathrm{PI}^{-}\right)$shows living cells; LR quadrant $\left(\mathrm{FITC}^{+} / \mathrm{PI}^{-}\right)$represents early apoptotic cells; UR quadrant $\left(\mathrm{FITC}^{+} / \mathrm{PI}^{+}\right)$stands for late apoptotic cells and UL quadrant $\left(\mathrm{FITC}^{+} / \mathrm{PI}^{+}\right)$stands for necrotic cells. (B) Western blot analysis of cleaved caspase 3 and cleaved PARP performed after $24 \mathrm{~h}$ incubation. Cells analyzed to examine cell death by measuring cleaved caspase 3 and cleaved PARP detected by Western blotting. In all the above experiments, whole cell lysates were prepared for subsequent separation by polyacrylamide gel electrophoresis followed by Western blot analysis. Imaging and analysis performed as described earlier. ${ }^{*} p<0.05,{ }^{* * *} p<0.001$ as compared with either individual OC or LP treatment or vehicle treatment. 


\subsection{Effect of Combined OC-LP Treatment on Cell Protein Array Assay in BT-474 BC Cells}

A high-throughput ELISA-based antibody microarray was performed to identify candidate proteins and signaling pathways associated with the molecular effects of combined OC-LP treatment in BT-474 cells (Supplementary Figure S2). Microarray analysis data demonstrated that combination treatment suppressed phosphorylation of multiple molecular targets, including HER-2, FAK, JAK1 and MEK2 (Supplementary Figure S2). Alternatively, the combined OC-LP treatment exerted little effect on the phosphorylation of IGF-1R in treated BT-474 cells (Supplementary Figure S2).

\subsection{Effect of Combined OC-LP Treatment on Migration and Invasion of HER2-Positive BC Cells and Downstream Signaling Effectors}

Combined OC-LP treatment inhibited the migration and invasion of both HER2-positive breast cancer cell lines, compared to vehicle-treated control cells, as well as OC or LP individual treatments (Figure 5). Western blot analysis further demonstrated molecular pathways significantly altered by the anti-migratory and anti-invasive effects of combination treatment in cancer cells in compared to OC or LP individual treatment. In both BT-474 and SK-BR-3 cells, combined OC-LP treatments resulted in reduced both total, as well as phosphorylated levels of FAK, compared to vehicle control-treated cells (Figure 5). Individual OC treatment also reduced the total level of FAK in SK-BR-3 cells while the suppression of paxillin and its phosphorylated form was more evident for combination treatment on both SK-BR-3 cells and BT-474 cells (Figure 5). Multiple mitogenic signaling pathways significantly suppressed by combined OC-LP treatment, including the STAT and mitogen-activated protein kinase (MAPK) in both BT-474 and SK-BR-3 cells, compared to individual OC or LP treatment (Figure 5).

\subsection{Effects of Combined OC-LP in BT-474 Tumor Xenografts in Nude Mouse Model}

The anti-tumor effect of combined OC-LP treatment was investigated in vivo in an orthotopic xenograft tumor model of BT-474 cells in nude mice. The mean tumor weight for the vehicle-treated control group was $1490.32 \pm 273.10 \mathrm{mg}$ at the end of treatment duration. The mean tumor weight for the $10.0 \mathrm{mg} / \mathrm{kg}$ OC-treated group was $191.86 \pm 40.92 \mathrm{mg}$. The mean tumor volume was $1248.52 \pm 274.73$, and $74.19 \pm 9.47 \mathrm{~mm}^{3}$ for vehicle control and $10.0 \mathrm{mg} / \mathrm{kg}$ OC-treated mice groups, respectively (Figure 6A). The OC $10.0 \mathrm{mg} / \mathrm{kg}$ treatments resulted in $>90 \%$ tumor growth reduction compared to vehicle-treated control animals. The mean tumor weight for the $12.5 \mathrm{mg} / \mathrm{kg}$ LP-treated group was $228.42 \pm 19.85 \mathrm{mg}$ and the mean tumor volume for the same treatment was $230.73 \pm 8.83$ $\mathrm{mm}^{3}$. LP treatment at $12.5 \mathrm{mg} / \mathrm{kg}$ resulted in $81.21 \%$ tumor growth reduction, compared to vehicle control-treated mice.

Interestingly, co-administration of $12.5 \mathrm{mg} / \mathrm{kg} \mathrm{LP}$ with $10 \mathrm{mg} / \mathrm{kg}$ OC resulted in the greatest tumor growth inhibition, compared to the vehicle and monotherapy controls. Post-hoc analysis showed a significant difference in the mean tumor weight or volume between the monotherapy OC or LP and the combination-treated group. Combined $12.5 \mathrm{mg} / \mathrm{kg} \mathrm{LP}$ with $10 \mathrm{mg} / \mathrm{kg}$ OC-treated group resulted in a mean tumor weight of $51.25 \pm 8.05 \mathrm{mg}$ (Figure 6A) and mean tumor volume of $4.87 \pm 0.44 \mathrm{~mm}^{3}$ (Figure 6B). Combined treatment resulted in over $99.0 \%$ tumor growth inhibition, compared to vehicle control-treated mice. All treatments did not cause gross changes in the body weight of the treated animals (Figure 6D). Western blot analysis of isolated mice tumors collected at the experiment end showed the downregulation of the total levels of HER2, EGFR, and c-Met in LP-OC combination-treated group. Combination treatment also caused significant downregulation of the p-HER2, p-EGFR, and p-c-Met active levels in comparison to the OC or LP individual treatments (Figure 6E and Supplementary Figure S3). Further, Western blot of mice tumors also revealed increased levels of the arrest proteins p27 and p21 for the combination-treated group, which was associated with a reduced phosphorylated active level of AKT (Figure 6E and Supplementary Figure S3).

Histopathological analysis of various group tumors revealed the lack of defined capsule in tumors from untreated control tumor cells (Figure 6F). Mice tumors treated with the individual $10 \mathrm{mg} / \mathrm{kg}$ OC were encapsulated and tumor cells presented small, pyknotic nuclei and clear cytoplasm (Figure 6F). 
Occasional focal areas of necrosis were also observed. Mitotic cells were infrequent. LP $12.5 \mathrm{mg} / \mathrm{kg}$ treatment showed tumors with highly pleomorphic cells, frequent large lipid vacuoles and mitotic figures dispersed throughout the tumor section (Figure 6F). Large cells with chromosome fragmentation and apoptotic cells were also frequently observed. Mice treated with combined OC $10 \mathrm{mg} / \mathrm{kg}$ plus LP $12.5 \mathrm{mg} / \mathrm{kg}$ showed small nests of tumor cells within the connective tissue stroma. Tumor cells showed pyknotic nuclei, evident apoptotic cells, and rare mitosis (Figure 6F).

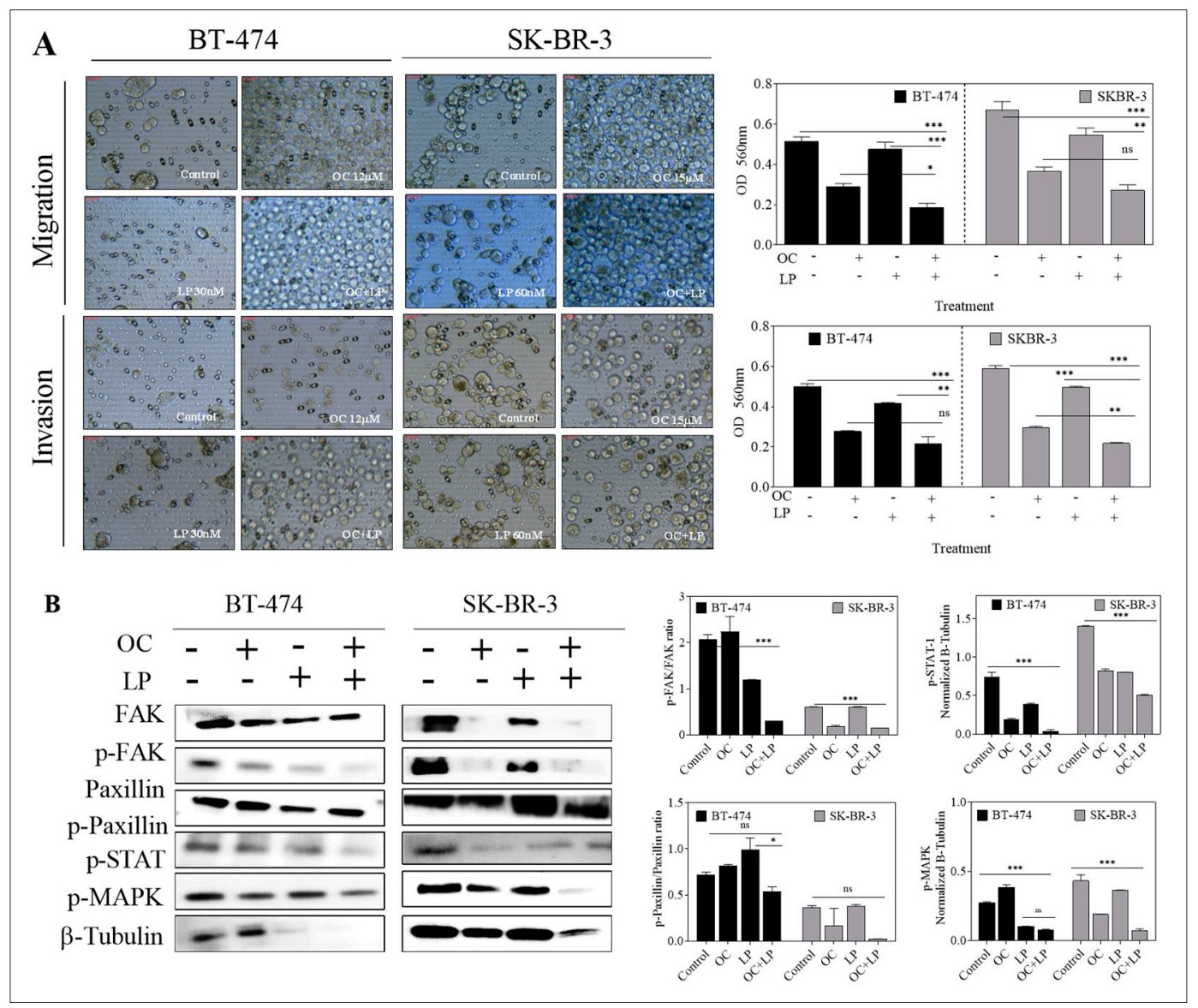

Figure 5. Effect of combined OC and LP treatment on migration and invasion of HER2-positive BC cells and downstream signaling effectors. (A) Effect of OC and LP treatment on migration and invasion of BT-474 and SK-BR-3 BC cells. Optical density in migration and invasion assay in BT-474 and SK-BR-3 cells. Cells were seeded according to the manufacturer protocol and as described in "Methods". In both assays, the provided images were taken for the upper surface of the inserts (B) Western blot analysis for the effect of combined OC and LP treatment on total and active levels of proteins controlling cell migration and invasion. Whole cell lysates were prepared for separation by polyacrylamide gel electrophoresis followed by Western blot analysis. Imaging and analysis were performed as mentioned earlier. ${ }^{*} p<0.05,{ }^{* * *} p<0.001$ as compared with either individual OC or LP treatment or vehicle treatment. ns, not statistically significant. 


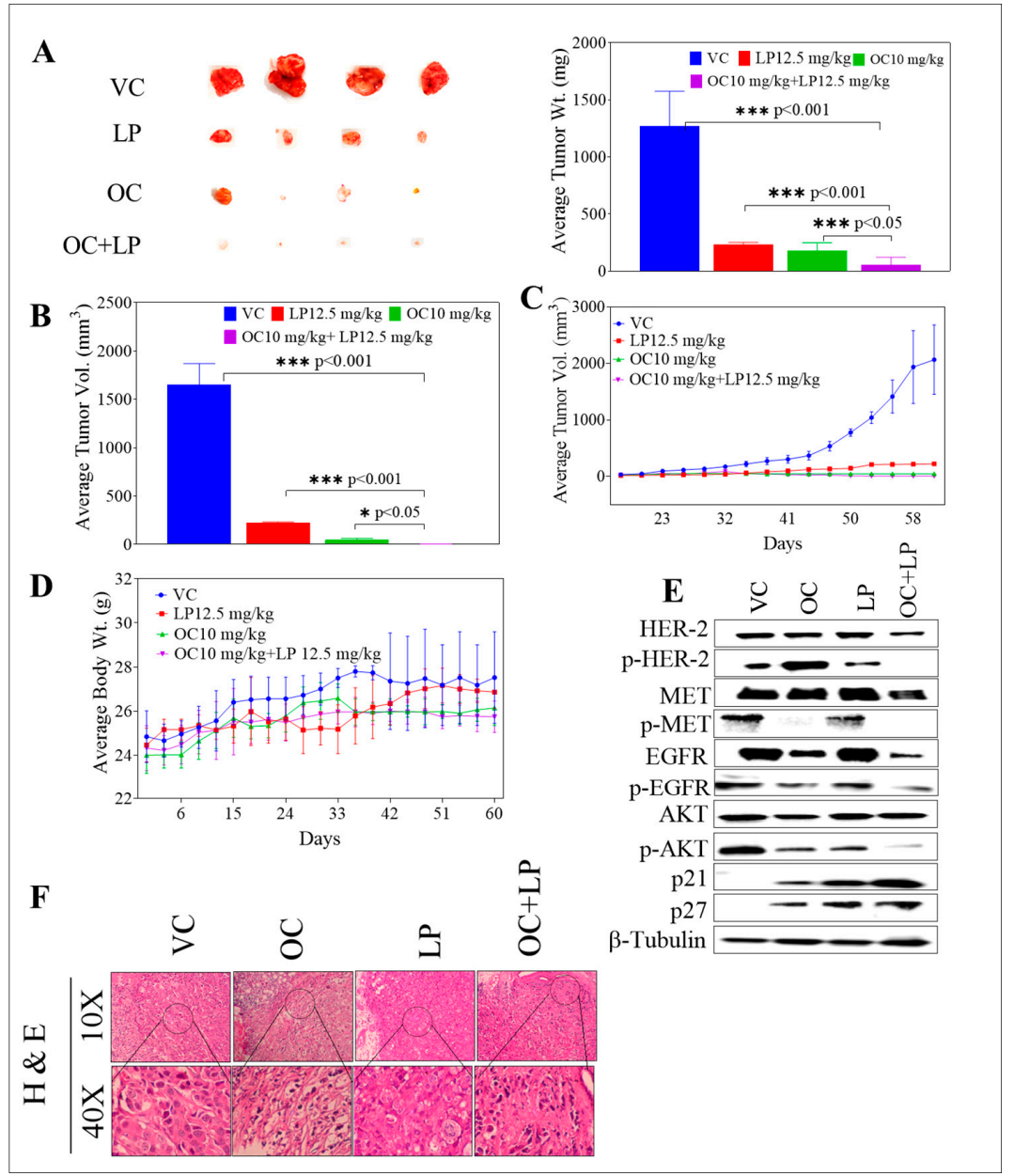

Figure 6. Effect of OC-LP combination treatment on tumor growth in BT-474 BC cells xenograft model. (A) Left panel. Representative isolated mice tumors of each experimental group collected at end of the experiment. Top row is the vehicle-treated control group, then the $12.5 \mathrm{mg} / \mathrm{kg} \mathrm{LP}$, oral, 5X/week, the $10 \mathrm{mg} / \mathrm{kg}$ OC, ip, 3X/week, and finally the bottom row represents the combined $10 \mathrm{mg} / \mathrm{kg} \mathrm{OC}$, ip, $3 \mathrm{X} /$ week $-12.5 \mathrm{mg} / \mathrm{kg} \mathrm{LP}$, oral, $5 \mathrm{X} /$ week-treated group. Right panel. The mean tumor weight at the end of the experiment vertical bars graph. (B) The mean tumor volume at the end of the experiment vertical bars graph. The tumor volume $(\mathrm{V})$ was calculated as $\mathrm{V}=\left(\mathrm{L} \times \mathrm{W}^{2}\right) / 2$, where $\mathrm{L}$ was the length and $W$ was the width of tumors. Bars \pm SEM. ${ }^{* * *} p<0.001$ as compared with either individual OC or LP treatment or vehicle treatments. (C) Tumor volumes monitoring over the course of the experiment. Points represent the mean tumor volume of several tumors $(n=5)$ in each experimental group over the treatment period. Error bars indicate SEM for $n=5$. (D) Body weight monitoring of mice over the experiment course. Points represent mean body weight for animals in each group $(n=5)$ over the experiment duration. Error bars indicate SEM for $n=5$. (E) Western blot analysis of various experimental groups for the total and active levels of study target RTKs and their downstream signaling proteins. (F) H\&E staining of tumor samples in different study groups. Human BC cells BT-474 cultured and suspended in serum-free RPMI medium with (30:30) $\mu$ L Matrigel. Cell suspensions $\left(5 \times 10^{6}\right.$ cells $\left./ 60 \mu \mathrm{L}\right)$ subcutaneously inoculated into the second mammary gland fat pad just beneath the nipple of each athymic nude mouse to generate orthotropic breast tumor xenografts. One day before tumor cells inoculation, a 0.72-mg 60-day release 17 $\beta$-estradiol pellet (Innovative Research) surgically implanted into the interscapular region of each mouse. Once the tumor is palpable, $\sim 35 \mathrm{~mm}^{3}$ volume around the 14th day, mice were randomly divided into four groups, $n=5$ each: (i) The vehicle-treated control group; (ii) the $10.0 \mathrm{mg} / \mathrm{kg}$ OC-treated group; (iii) the $12.5 \mathrm{mg} / \mathrm{kg}$ LP-treated group; and (iv) the OC $10.0 \mathrm{mg} / \mathrm{kg}$ plus LP $12.5 \mathrm{mg} / \mathrm{kg}$ - treated group. Oral treatments, vehicle control (DMSO/saline), OC, LP, and OC-LP combination, started 14 days post-inoculation and continued until the 60th day. 


\section{Discussion}

Overexpression of HER2 protein is associated with aggressive tumor profile and poor clinical outcomes among BC patients diagnosed with HER2-positive phenotype [36,37]. Approximately $20 \%$ of human BC cases are HER2-amplified [36,37]. Multiple HER2-targeted agents have been already approved and in clinical practice for HER2-positive malignancies. Lapatinib (LP) is a small-molecule dual inhibitor of both EGFR and HER2 [9-11].

HGF/c-Met axis has been shown to strongly contribute to the development and progression of BC [17,38-40]. c-Met/HGF axis is dysregulated in $20-30 \%$ of clinical BC cases and is a valid and independent predictor of poor patient prognosis [39,40]. On the molecular level, the crosstalk between c-Met and HER family has been extensively studied [19-21]. c-Met can form heterodimers with EGFR, HER2, and HER3 in lung cancer cells [41]. These heterodimers have differential roles in tumor development in lung cancer with c-Met amplification [41]. In addition, ligand-dependent hetero-dimerization of HER family and c-Met has been shown to enhance activation of multiple downstream signaling pathways, including Src, PI3K-AkKT-mTOR, and Ras-MAPK [42,43].

Dysregulation of HGF/c-Met axis promotes acquired resistance to cancer cells treated with HER family targeted therapies [20-22,43,44]. Therefore, despite the proven clinical benefits of LP, multiple cancer cell phenotypes commonly escape its therapeutic effects through the activation of alternative survival pathways, including HGF/c-Met pathway [20,36,44-48]. Extended LP use can even induce cancer cell proliferation by promoting atypical multi-HER family heterodimerization [49]. Therefore, combining a c-Met inhibitor with LP provides a promising approach to chemosensitize the HER2-positive tumor cells and reduce resistance emergence through c-Met pathway activation $[36,44,50]$.

The results of this study demonstrated the synergistic effect of combined treatment of LP with the EVOO phenolic OC against wild type HER-2-positive BC cells. Because of its well-documented activity in inhibiting c-Met activation [27], OC combined with LP in this study to further investigate possible improved therapeutic effects of this novel combination against the HER2-positive BC cells. OC-LP combination resulted in synergistic growth inhibition of the HER-2 positive BC cell lines BT-474 and SK-BR-3. Both cell lines have been shown to co-express HER2 and c-Met and were sensitive to targeted inhibitors of these receptors. Growth inhibition was associated with reduced activation of HER2, EGFR, and c-Met (Figure 3). The suppression of RTKs activation observed with combined OC-LP resulted in subsequent inhibition of multiple downstream survival and mitogenic signaling pathways in HER2-positive cells, including the PI3K, MAPK, and STAT pathways (Figure 5). In addition, the anti-proliferative activity of the combined OC-LP treatment was mediated, in-part, by the induction of G1 cell cycle arrest in cancer cells as indicated by upregulation of arrest proteins p21 and p27 and reduced levels of cyclins and cyclin D kinases (CDKs, Supplementary Figure S1). Of specific interest is the significant OC-LP combined treatment enhancement for the p21 level, which is a p53-independent master effector of multiple tumor suppressor pathways, promoting and justifying the synergistic anti-proliferative effects especially in HER2/estrogen-positive BC [51].

The synergistic interaction between OC and LP in this study enhanced cancer cell sensitivity to LP treatment evidenced by multi-fold reductions for LP concentration when combined with a sub-effective dose of OC. Combining OC with LP reduced its required $\mathrm{IC}_{50}$ dose to nearly $1 / 4$ th or $1 / 3$ rd of its original cytotoxic dose against BT-474 and SK-BR-3 cells, respectively (Supplementary Table S1). Isobologram analysis of the effect of OC-LP combination treatments in both cell lines indicated synergistic inhibition of cell growth (Figure 2). Combined OC-LP treatments induced apoptosis in SK-BR-3 cells as determined by detectable levels of cleaved caspase 3 and cleaved PARP in treated cells, compared to vehicle-controls (Figure 4C) while combined treatment in BT-474 cell showed a clear cytostatic effect, as indicated by the lack of the cleaved caspase 3 and cleaved PARP in treated cells. BC cell lines used in this study have different molecular profiles, doubling times, and expression of alternative growth signaling pathways. BT-474 cells represent luminal B type, estrogen, progesterone, and HER2 positive [32]. SK-BR-3 cells are positive to HER2, but negative to both estrogen and progesterone receptors [32]. 
OC-LP combination treatment suppressed ligand (HGF and EGF)-induced migration and invasion of HER2-positive BC cells. The anti-migratory and anti-invasive activities for the OC-LP combination were primarily mediated by reduced FAK and paxillin levels and activation in both BT-474 and SK-BR-3 cells (Figure 5), compared to individual OC or LP treatment. These findings are of particular significance because migration and invasion are critical steps for subsequent tumor cell metastasis, an event associated with high cancer-related mortality [17,37].

Earlier clinical data demonstrated a greater benefit of LP treatment among HER2-amplified $\mathrm{BC}$ patients and hormone receptor negative status, compared to those who were hormone receptor positive [45]. In line with this, this study in vitro data indicated monotherapy decreased the sensitivity of BT-474 cells to LP as a result of expression of hormone receptors [45], meanwhile combination treatment showed significant sensitivity as compared to control and individual treatment. This may be due to earlier proven ability of OC to show anti-estrogenic and ER expression reducing effects, in vitro and in vivo [28].

Combined OC (10 mg/kg)-LP (12.5 mg/ $\mathrm{kg}$ ) remarkably suppressed BT-474 tumor growth in a xenograft mouse model (Figure 6). The combined treatment lacked preliminary systemic toxicity as indicated by the sustained normal body weight of treated mice groups (Figure 6D). The significant tumor growth inhibition in combination-treated mice was mediated by reduced total and active levels of HER2, EGFR, and c-Met, compared to individual OC or LP treatments (Figure 6E), suggesting effective tumor cell sensitization. Histopathological examination of the tumor sections collected from combination treatment mice group showed significant lack of mitotic tumor cells, compared to vehicle control and individual OC and LP-treated mice, which further validate the in vivo OC-LP combination synergy and efficacy (Figure 6F).

\section{Conclusions}

Combination of OC as a c-Met inhibitor with the dual HER2/EGFR inhibitor LP induced synergistic growth inhibition for the mitogen-mediated growth of HER2-positive breast cancer cells in vitro and in vivo. Thus, OC appears as an appealing c-Met lead natural product inhibitor that could boost the activity of the HER-targeting therapies, represented by LP, at concentrations that had no remarkable effects on the viability of non-tumorigenic cells (Figure 1). Mechanistically, introducing OC as a c-Met inhibitor in combination with LP treatment would allow the use of reduced doses of targeted therapies like LP, which would reduce future resistance emergence and drug toxicity while maintaining maximal therapeutic activity. Meanwhile, to reach the therapeutic dose of $10 \mathrm{mg} / \mathrm{kg}$ in humans, it would be required to consume every day about $700 \mathrm{~mL}$ of the best quality EVOO, averaging OC natural occurrence of $1 \mathrm{~g} / \mathrm{L}$, highlighting the future need to use formulated pure OC as a dietary supplement for therapeutic applications.

Supplementary Materials: The following are available online at http:/ / www.mdpi.com/2072-6643/11/2/412/ s1. Table S1: Combination index and dose reduction index values for OC-LP combined treatment, Figure S1. Flow cytometry analysis for cell cycle progression, Figure S2. Effect of combined OC and LP treatment on cell protein array assay, Figure S3. Densitometric quantification of pHER-2, p-Met, p-EGFR, and others.

Author Contributions: Author Contributions: A.B.S. and K.A.E. conceived and designed the experiments; A.B.S., H.Y.E., M.R.A., A.A.G., M.M.M., S.K.N., performed the experiments; A.B.S., H.Y.E., N.M.A., W.M.H, Y.-Y.L., S.A.M. analyzed the data; K.A.E. contributed reagents/materials/analysis tools; A.B.S., N.M.A., and K.A.E. wrote the manuscript.

Funding: This research was funded by the Louisiana Board of Regents, Award Number LEQSF (2017-20)-RD-B-07) and the National Cancer Institute of the National Institutes of Health under Award Number R15CA167475. The APC was funded by both of the abovementioned awards indirect costs to University of Louisiana-Monroe recovered to K. El Sayed.

Acknowledgments: The Dafnis family, Corfu Island, Greece, is acknowledged for generously offering the oleocanthal source Governor EVOO.

Conflicts of Interest: K. El Sayed is a Medicinal Chemistry Chief Scientific Officer without compensation in the Shreveport, Louisiana-based Oleolive. 


\section{Abbreviations}

$\begin{array}{ll}\text { OC } & \text { (-)-Oleocanthal } \\ \text { LP } & \text { Lapatinib } \\ \text { c-Met } & \text { Mesenchymal-epithelial transition factor } \\ \text { EGFR } & \text { Epidermal growth factor receptor } \\ \text { HER } & \text { Human epidermal growth factor receptor } \\ \text { FAK } & \text { Focal Adhesion Kinase } \\ \text { AKT } & \text { Protein kinase B } \\ \text { PI3K } & \text { Phosphoinositide 3-kinase } \\ \text { MAPK } & \text { Mitogen-activated protein kinase } \\ \text { JAK } & \text { Janus kinase } \\ \text { STAT-3 } & \text { Signal transducer and activator of transcription 3 } \\ \text { HSP90 } & \text { Heat shock protein 90 } \\ \text { RPMI } & \text { Roswell Park Memorial Institute } \\ \text { FBS } & \text { Fetal bovine serum } \\ \text { DMEM } & \text { Dulbecco's Modified Eagle's medium } \\ \text { EDTA } & \text { Ethylenediaminetetraacetic acid } \\ \text { NMR } & \text { Nuclear magnetic resonance } \\ \text { DMSO } & \text { Dimethyl sulfoxide } \\ \text { MTT } & \text { 3-(4,5-dimethylthiazol-2-yl)-2,5-diphenyl-tetrazolium bromide } \\ \text { BC } & \text { Breast cancer } \\ \text { BCA } & \text { Bicinchoninic acid assay } \\ \text { BSA } & \text { Bovine serum albumin } \\ \text { DNA } & \text { Deoxyribonucleic acid } \\ \text { FITC } & \text { Fluorescein isothiocyante } \\ \text { CDK-6 } & \text { Cyclin-dependent kinase-6 } \\ \text { PARP } & \text { Poly (ADP-ribose) polymerase } \\ \text { CI } & \text { Combination index } \\ \text { DRI } & \text { Dose reduction index } \\ \text { EGF } & \text { Epidermal growth factor } \\ \text { ELISA } & \text { Enzyme-linked immunosorbent assay } \\ \text { EVOO } & \text { Extra-virgin olive oil } \\ \text { HGF } & \text { Hepatocyte growth factor } \\ \text { HPLC } & \text { High performance liquid chromatography } \\ \text { mTOR } & \text { Mechanistic target of rapamycin } \\ \text { PBS } & \text { Phosphate buffered saline } \\ \text { PI } & \text { Propidium iodide } \\ \text { TKIs } & \text { Tyrosine kinase inhibitors } \\ \text { UV } & \text { Ultraviolet } \\ & \end{array}$

\section{References}

1. Konecny, G.E.; Pegram, M.D.; Venkatesan, N.; Finn, R.; Yang, G.; Rahmeh, M.; Untch, M.; Rusnak, D.W.; Spehar, G.; Mullin, R.J.; et al. Activity of the dual kinase inhibitor lapatinib (GW572016) against HER-2-overexpressing and trastuzumab-treated breast cancer cells. Cancer Res. 2006, 66, 1630-1639. [CrossRef]

2. Slamon, D.J.; Clark, G.M.; Wong, S.G.; Levin, W.J.; Ullrich, A.; McGuire, W.L. Human breast cancer: Correlation of relapse and survival with amplification of the HER-2/neu oncogene. Science 1987, 235, 177-182. [CrossRef]

3. Liu, X.; Abdelrahim, M.; Abudayyeh, A.; Lei, P.; Safe, S. The nonsteroidal anti-inflammatory drug tolfenamic acid inhibits BT474 and SKBR3 breast cancer cells and tumor growth by repressing erbB2 expression. Mol. Cancer Ther. 2009, 8, 1207-1217. [CrossRef] 
4. Burstein, H.J. The distinctive nature of HER2-positive breast cancers. N. Engl. J. Med. 2005, 353, $1652-1654$. [CrossRef]

5. Mitri, Z.; Constantine, T.; O'Regan, R. The HER2 receptor in breast cancer: Pathophysiology, clinical use, and new advances in therapy. Chemother. Res. Pract. 2012, 2012, 743193. [CrossRef]

6. Scheuer, W.; Friess, T.; Burtscher, H.; Bossenmaier, B.; Endl, J.; Hasmann, M. Strongly enhanced antitumor activity of trastuzumab and pertuzumab combination treatment on HER2-positive human xenograft tumor models. Cancer Res. 2009, 69, 9330-9336. [CrossRef]

7. Giuliano, M.; Hu, H.; Wang, Y.; Fu, X.; Nardone, A.; Herrera, S.; Mao, S.; Contreras, A.; Gutierrez, C.; Wang, T.; et al. Upregulation of ER signaling as an adaptive mechanism of cell survival in HER2-positive breast tumors treated with anti-HER2 therapy. Clin. Cancer Res. 2015, 21, 3995-4003. [CrossRef]

8. Wang, F.; Dohogne, Z.; Yang, J.; Liu, Y.; Soibam, B. Predictors of breast cancer cell types and their prognostic power in breast cancer patients. BMC Genom. 2018, 19, 137. [CrossRef]

9. Callahan, R.; Hurvitz, S. Human epidermal growth factor receptor-2-positive breast cancer: Current management of early, advanced, and recurrent disease. Curr. Opin. Obstet. Gynecol. 2011, 23, 37-43. [CrossRef]

10. Rusnak, D.W.; Affleck, K.; Cockerill, S.G.; Stubberfield, C.; Harris, R.; Page, M.; Smith, K.J.; Guntrip, S.B.; Carter, M.C.; Shaw, R.J.; et al. The characterization of novel, dual ErbB-2/EGFR, tyrosine kinase inhibitors: Potential therapy for cancer. Cancer Res. 2001, 61, 7196-7203.

11. Patrick, J.; Susan, G. Lapatinib: A dual inhibitor of human epidermal growth factor receptor tyrosine kinases. Clin. Ther. 2008, 30, 1426-1447.

12. Rusnak, D.W.; Lackey, K.; Affleck, K.; Wood, E.R.; Alligood, K.J.; Rhodes, N.; Keith, B.R.; Murray, D.M.; Knight, W.B.; Mullin, R.J.; et al. The effects of the novel, reversible epidermal growth factor receptor/ErbB-2 tyrosine kinase inhibitor, GW2016, on the growth of human normal and tumor-derived cell lines in vitro and in vivo. Mol. Cancer Ther. 2011, 1, 85-94.

13. Burris, H.A. Dual kinase inhibition in the treatment of breast cancer: Initial experience with the EGFR/ErbB-2 inhibitor lapatinib. Oncologist 2004, 9, 10-15. [CrossRef]

14. Leto, S.M.; Trusolino, L. Primary and acquired resistance to EGFR-targeted therapies in colorectal cancer: Impact on future treatment strategies. J. Mol. Med. 2014, 92, 709-722. [CrossRef]

15. Rubin, B.P.; Duensing, A. Mechanisms of resistance to small molecule kinase inhibition in the treatment of solid tumors. Lab. Investig. 2006, 86, 981-986. [CrossRef]

16. Miekus, $\mathrm{K}$. The Met tyrosine kinase receptor as a therapeutic target and a potential cancer stem cell factor responsible for therapy resistance (Review). Oncol. Rep. 2017, 37, 647-656. [CrossRef]

17. Furlan, A.; Kherrouche, Z.; Montagne, R.; Copin, M.C.; Tulasne, D. Thirty years of research on Met receptor to move a biomarker from bench to bedside. Cancer Res. 2014, 74, 6737-6744. [CrossRef]

18. Sharial, M.S.N.; Crown, J.; Hennessy, B.T. Overcoming resistance and restoring sensitivity to HER2-targeted therapies in breast cancer. Ann. Oncol. 2012, 23, 3007-3016. [CrossRef]

19. Viticchiè, G.; Muller, P.A.J. c-Met and other cell surface molecules: Interaction, activation and functional consequences. Biomedicines 2015, 3, 46-70. [CrossRef]

20. Chen, C.T.; Kim, H.; Liska, D.; Gao, S.; Christensen, J.G.; Weiser, M.R. MET Activation mediates resistance to lapatinib inhibition of HER2-amplified gastric cancer cells. Mol. Cancer Ther. 2012, 11, 660-669. [CrossRef]

21. Engelman, J.A.; Zejnullahu, K.; Mitsudomi, T.; Song, Y.; Hyland, C.; Park, J.O.; Lindeman, N.; Gale, C.M.; Zhao, X.; Christensen, J.; et al. Met amplification leads to gefitinib resistance in lung cancer by activating ERBB3 signaling. Science 2007, 316, 1039-1043. [CrossRef]

22. Shattuck, D.L.; Miller, J.K.; Carraway, K.L.; Sweeney, C. Met receptor contributes to trastuzumab resistance of Her2-overexpressing breast cancer cells. Cancer Res. 2008, 68, 1471-1477. [CrossRef]

23. Carlos, L.; Sliwkowski, A.M.X.; Osborne, C.K.; Perez, E.G.; Puglisi, F.; Gianni, L. Treatment of HER2-positive breast cancer: Current status and future perspectives. Nat. Rev. Clin. Oncol. 2012, 9, 16-32.

24. Beauchamp, G.K.; Keast, R.S.; Morel, D.; Lin, J.; Pika, J.; Han, Q.; Lee, C.H.; Smith, A.B.; Breslin, P.A. Phytochemistry: Ibuprofen-like activity in extra-virgin olive oil. Nature 2005, 437, 45-46. [CrossRef]

25. Parkinson, L.; Keast, R. Oleocanthal, a phenolic derived from virgin olive oil: A review of the beneficial effects on inflammatory disease. Int. J. Mol. Sci. 2014, 15, 12323-12334. [CrossRef]

26. Elnagar, A.Y.; Sylvester, P.W.; El Sayed, K.A. (-)-Oleocanthal as a c-Met inhibitor for the control of metastatic breast and prostate cancers. Planta Med. 2011, 77, 1013-1019. [CrossRef] 
27. Akl, M.R.; Ayoub, N.M.; Mohyeldin, M.M.; Busnena, B.A.; Foudah, A.I.; Liu, Y.Y.; EI Sayed, K.A. Olive phenolics as c-Met inhibitors: (-)-Oleocanthal attenuates cell proliferation, invasiveness, and tumor growth in breast cancer models. PLoS ONE 2014, 9, e97622. [CrossRef]

28. Ayoub, N.M.; Siddique, A.B.; Ebrahim, H.Y.; Mohyeldin, M.M.; El Sayed, K.A. The olive oil phenolic $(-)$-oleocanthal modulates estrogen receptor expression in luminal breast cancer in vitro and in vivo and synergizes with tamoxifen treatment. Eur. J. Pharmacol. 2017, 81, 100-111. [CrossRef]

29. El Sayed, K.A.; Siddique, A.; Ebrahim, H. Oleocanthal Isolation and Cancer Treatment. PCT/US2017/043308, WO2018/017967. 2017. Available online: https://patentscope.wipo.int/search/docservicepdf_pct/ id00000040957785/PAMPH/WO2018017967.pdf?psAuth=O-ES4V5VQFvvBx0R8cXgCcXhWkCtUmM_ m685wbwH8T0 (accessed on 1 December 2018).

30. Mohyeldin, M.M.; Akl, M.R.; Ebrahim, H.Y.; Dragoi, A.M.; Dykes, S.; Cardelli, J.A.; El Sayed, K.A. The oleocanthal-based homovanillyl sinapate as a novel c-Met inhibitor. Oncotarget 2016, 7, 32247-32273. [CrossRef]

31. Pang, K.L.; Chin, K.Y. The biological activities of oleocanthal from a molecular perspective. Nutrients 2018, 6, 5. [CrossRef]

32. Holliday, D.L.; Speirs, V. Choosing the right cell line for breast cancer research. Breast Cancer Res. 2011, 13, 215. [CrossRef]

33. Riss, T.L.; Moravec, R.A.; Niles, A.L.; Duellman, S.; Benink, H.A.; Worzella, T.J.; Minor, L. Cell Viability Assays. In Assay Guidance Manual; Weidner, J., Ed.; Eli Lilly \& Company and the National Center for Advancing Translational Sciences: Bethesda, MD, USA, 2004. Available online: https:/ /www.ncbi.nlm.nih. gov/books/NBK144065/ (accessed on 1 December 2018). [PubMed]

34. National Research Council. Guide for the Care and Use of Laboratory Animals; The National Academies Press: Washington, DC, USA, 2011. Available online: http:/ / grants.nih.gov/grants/olaw/Guide-for-the-Careand-Use-of-Laboratory-Animals.pdf. (accessed on 11 July 2018).

35. Chou, T.C. Drug combination studies and their synergy quantification using the Chou-Talalay method. Cancer Res. 2010, 70, 440-446. [CrossRef]

36. Wang, Y.C.; Morrison, G.; Gillihan, R.; Guo, J.; Ward, R.M.; Fu, X.; Botero, M.F.; Healy, N.A.; Hilsenbeck, S.G.; Phillips, G.L.; et al. Different mechanisms for resistance to trastuzumab versus lapatinib in HER2- positive breast cancers role of estrogen receptor and HER2 reactivation. Breast Cancer Res. 2011, 13, R121. [CrossRef]

37. Figueroa-Magalhães, M.C.; Jelovac, D.; Connolly, R.; Wolff, A.C. Treatment of HER2-positive breast cancer. Breast 2014, 23, 128-136. [CrossRef]

38. Rho, O.; Kim, D.J.; Kiguchi, K.; DiGiovanni, J. Growth factor signaling pathways as targets for prevention of epithelial carcinogenesis. Mol. Carcinog. 2011, 50, 264-279. [CrossRef]

39. Gonzalez-Angulo, A.M.; Chen, H.; Karuturi, M.S.; Chavez-MacGregor, M.; Tsavachidis, S.; Meric-Bernstam, F.; Blumenschein, G.R. Frequency of MET and PIK3CA copy number elevation and correlation with outcome in early stage breast cancer. Cancer 2013, 119, 7-15. [CrossRef]

40. Ponzo, M.G.; Lesurf, R.; Petkiewicz, S.; O’Malley, F.P.; Pinnaduwage, D.; Andrulis, I.L.; Park, M. Met induces mammary tumors with diverse histologies and is associated with poor outcome and human basal breast cancer. Proc. Natl. Acad. Sci. USA 2009, 106, 12903-12908. [CrossRef]

41. Tanizaki, J.; Okamoto, I.; Sakai, K.; Nakagawa, K. Differential roles of trans-phosphorylated EGFR, HER2, HER3, and RET as heterodimerisation partners of MET in lung cancer with MET amplification. Br. J. Cancer 2011, 105, 807-813. [CrossRef]

42. Breindel, J.L.; Haskins, J.W.; Cowell, E.P.; Zhao, M.; Nguyen, D.X.; Stern, D.F. EGF Receptor activates MET through MAP kinases to enhance non-small cell lung carcinoma invasion and brain metastasis. Cancer Res. 2013, 73, 5053-5065. [CrossRef]

43. Dulak, A.M.; Gubish, C.T.; Stabile, L.P.; Henry, C.; Siegfried, J.M. HGF-independent potentiation of EGFR action by c-Met. Oncogene 2011, 30, 3625-3635. [CrossRef]

44. Yano, S.; Wang, W.; Li, Q.I.; Matsumoto, K.; Sakurama, H.; Nakamura, T.; Ogino, H.; Kakiuchi, S.; Hanibuchi, M.; Nishioka, Y.; et al. Hepatocyte growth factor induces gefitinib resistance of lung adenocarcinoma with epidermal growth factor receptor-activating mutations. Cancer Res. 2008, 68, 9479-9487. [CrossRef] [PubMed] 
45. Finn, R.S.; Press, M.F.; Dering, J.; Arbushites, M.; Koehler, M.; Oliva, C.; Di Leo, A. Estrogen receptor, progesterone receptor, human epidermal growth factor receptor 2 (HER2), and epidermal growth factor receptor expression and benefit from lapatinib in a randomized trial of paclitaxel with lapatinib or placebo as first-line treatment in HER2-negative or unknown metastatic breast cancer. J. Clin. Oncol. 2009, 27, 3908-3915. [CrossRef] [PubMed]

46. Liu, L.; Greger, J.; Shi, H.; Liu, Y.; Greshock, J.; Annan, R.; Halsey, W.; Sathe, G.M.; Martin, A.M.; Gilmer, T.M. Novel mechanism of lapatinib resistance in HER2-positive breast tumor cells: Activation of AXL. Cancer Res. 2009, 69, 6871-6878. [CrossRef] [PubMed]

47. Lopez-Albaitero, A.; Xu, H.; Guo, H.; Wang, L.; Wu, Z.; Tran, H.; Cheung, N.K.V. Overcoming resistance to HER2-targeted therapy with a novel HER2/CD3 bispecific antibody. Oncoimmunology 2017, 6, e1267891. [CrossRef] [PubMed]

48. Woo, J.; Cohen, S.A.; Grim, J.E. Targeted therapy in gastroesophageal cancers: Past, present and future. Gastroenterol. Rep. 2015, 3, 316-329. [CrossRef] [PubMed]

49. Claus, J.; Patel, G.; Autore, F.; Colomba, A.; Weitsman, G.; Soliman, T.N.; Roberts, S.; Zanetti-Domingues, L.C.; Hirsch, M.; Collu, F.; et al. Inhibitor-induced HER2-HER3 heterodimerisation promotes proliferation through a novel dimer interface. eLife 2018, 7, e32271. [CrossRef] [PubMed]

50. Liu, L.; Shi, H.; Liu, Y.; Anderson, A.; Peterson, J.; Greger, J.; Martin, A.M.; Gilmer, T.M. Synergistic effects of foretinib with HER-targeted agents in MET and HER1- or HER2- coactivated tumor cells. Mol. Cancer Ther. 2011, 10, 518-530. [CrossRef] [PubMed]

51. Abbas, T.; Dutta, A. p21 in cancer: Intricate networks and multiple activities. Nat. Rev. Cancer 2009, 9, 400-414. [CrossRef]

(C) 2019 by the authors. Licensee MDPI, Basel, Switzerland. This article is an open access article distributed under the terms and conditions of the Creative Commons Attribution (CC BY) license (http:/ / creativecommons.org/licenses/by/4.0/). 